\title{
Menjaga Daya Tahan Tubuh Dengan Olahraga Saat Pandemi Corona Covid-19
}

\author{
${ }^{1}$ Furkan, ${ }^{2}$ Rusdin, ${ }^{3}$ Shutan Arie Shandi \\ ${ }^{123}$ Pengajar di STKIP Taman Siswa Bima PRODI PJKR \\ Email: Furkanmaster007@ gmail.com
}

\begin{abstract}
Abstrak Sejak masuknya Covid-19 di Indonesia, masyarakt diminta untuk tetap di rumah dan melakukan segala sesuatu dari rumah. Selama di rumah saja mungkin banyak orang yang akhirnya sulit menjaga kesehatan karena tidak bisa berolahraga di luar rumah seperti biasanya atau terlalu banyak bermalas-malasan di rumah."Di saat WFH (work from home) seperti ini, karena pilihan kita cuma olahraga di rumah. Olahraga bisa meningkatkan imun system dan memperbaiki mood karena terus-terusan di rumah," kata Mario. Paling tidak dilakukan rutin 150 menit per pekan, tambahnya, 30 hingga 60 menit per sesi sebanyak 3-4 hari dalam sepekan.Rutinitas menjadi kunci dalam berolahraga dari rumah selama masa pandemi ini. akan sangat mudah bagi masyarakat jatuh ke dalam gaya hidup rebahan tiada henti. "Untuk itu, perlu membuat rutinitas harian di mana latihan fisik menjadi salah satu hal yang harus dilakukan setiap hari. Berolahraga setiap hari dapat memberikan perasaan terapeutik dan mengembalikan kehidupan menjadi lebih normal.
\end{abstract}

\section{Kata Kunci : Daya tahan tubuh, olahraga dan Pandemik Corona}

Abstract. Since the entry of Covid-19 in Indonesia, people have been asked to stay at home and do everything from home. While at home, maybe many people find it difficult to maintain their health because they cannot exercise outside the home as usual or they are lazing around too much at home. "When WFH (work from home) is like this, because our only choice is to exercise at home. "Exercise can increase the immune system and improve mood because you are constantly at home," said Mario. At least 150 minutes per week, he added, 30 to 60 minutes per session for 3-4 days a week. Routines are key in exercising from home during this pandemic. it will be very easy for people to fall into a relentless, lifestyles. "For that, it is necessary to create a daily routine in which physical exercise is one of the things that must be done every day. Exercising every day can provide a therapeutic feeling and bring life back to normal.

Keywords: Endurance, exercise and Corona Pandemic

\section{PENDAHULUAN}

Daya tahan tubuh yang kuat menjadi salah satu benteng menghadapi virus corona COVID-19. Olahraga teratur menjadi cara untuk menjaga kesehatan, kebugaran, dan daya tahan tubuh. Pakar Kedokteran Olahraga UGM, Zaenal Muttaqin Sofro, mengatakan ada banyak olahraga yang dapat dilakukan di rumah di tengah pandemi corona."Pada prinsipnya ada dua jenis olahraga yakni neural excercise/olahraga persarafan untuk menjaga kesehatan dan physical excercise/olahraga fisik untuk menjaga kebugaran. Olahraga tersebut bisa dilakukan di rumah olahraga persarafan diwujudkan dengan tiga cara yakni pernapasan, vokalisasi dan postur. Olahraga pernapasan bisa dilakukan dengan senam pernapasan seperti senam tera dan yoga. Lalu, vokalisasi antara lain dengan bersenandung, membaca Alquran dan lainnya. Sedangkan postur dapat ditempuh dengan cara seperti melakukan senam taichi maupun gerakan salat. Menurutnya, olahraga pernapasan ini dapat dilaksanakan setiap saat, kapan saja, dan di mana saja. Dengan melakukan olahraga pernapasan secara rutin dapat menjadikan tubuh sehat dan meminimalisir stres. "Saat ini kita kan dianjurkan menjalani physical distancing, berdiam diri di rumah. Karenanya, sangat tepat melakukan olahraga persarapan yang bisa dilakukan kapanpun 
Sementara untuk olahraga fisik, bisa dilakukan untuk membuat badan tetap bugar saat menjalankan aktivitas sehari-hari. Olahraga fisik ini melibatkan otot besar, bersifat ritmis, serta berkelanjutan. Saat melakukan olahraga fisik dianjurkan untuk tidak dilakukan secara berlebihan dengan intensitas tinggi. Sebab, hal tersebut bisa mengganggu kesehatan. "Banyak physical exercise yang justru mengganggu kesehatan karena over training maka harus benar benar mengacu FITT principle yakni frequency, intensity, time, and type," paparnya. Frekuensi olahraga fisik dapat dilakukan 3-5 kali per minggu, intensitas sedang, dan durasi selama 30-45 menit. Sedangkan jenis olahraga yang bisa dipilih seperti jalan cepat, jogging, bersepeda statis, senam, dan berenang. Sebelum memulainya didahului dengan pemanasan dan diakhiri pendinginan. Tidak kalah penting menjaga hidrasi agar selalu tercukupi cukup. Minum 30 menit sebelum berolahraga dan setelahnya guna mengganti jumlah cairan yang keluar lewat keringat. jika ingin berolahraga di luar ruangan saat pandemi corona /di luar rumah pastikan kondisi tubuh dalam keadaan fit dan direkomendasikan tetap menjaga jarak aman. Selain itu tetap menggunakan masker ketika berolahraga. Olahraga tidak harus dengan latihan fisik, tetapi bisa dengan latihan persyarafan. Olahraga ini dirasa tepat dilakukan dirumah ditengah pandemi COVID-19.

Demi Kekebalan Tubuh, Ini Anjuran Frekuensi Olahraga untuk Tangkal Corona Manfaat olahraga bukan sekadar bikin berkeringat. olahraga bermanfaat untuk kekebalan tubuh, dan bisa jadi salah satu cara untuk menangkal virus Corona Covid19 yang tengah mewabah.Olahraga bisa membuat Anda merasa lebih tenang dan membantu mencegah diri terinfeksi virus corona Covid-19 secara efektif.Tapi, Anda perlu mengetahui persis berapa banyak dan lamanya latihan fisik yang disarankan sebelum keluar lingkungan rumah untuk olahraga. Karena, olahraga terlalu berat dan lama atau tidak seimbang juga buruk bagi kesehatan tubuh.

Sebuah penelitian telah membuktikan bahwa olahraga bisa mempengaruhi sistem kekebalan tubuh. Karena itu, latihan fisik rutin dalam intensitas sedang bisa memberikan efek positif dengan mengurangi kerentanan kita terhadap infeksi. "Olahraga teratur adalah cara terbaik untuk mendukung sistem kekebalan tubuh. Karena olahraga membantu mendukung sirkulasi darah dengan baik. Kondisi ini memungkinkan selsel kekebalan tubuh melakukan fungsinya dengan baik," kata Frankie Brogan, Ahli Nutrisi Senior di Pharma Nord UK dikutip dari The Sun. Di sisi lain, terlalu banyak olahraga juga bisa memberikan efek sebaliknya yaitu kita lebih rentan terhadap penyakit. Secara khusus, tingkat olahraga yang benar bisa meningkatkan sistem kekebalan tubuh yang membantu melawan patogen penyebab penyakit.

Menurut sebuah penelitian dalam British Journal of Sprots Medicine, orang yang olahraga lima hari atau lebih dalam seminggu memiiki risiko 46 persen lebih kecil untuk terserang virus flu atau pernapasan. Berbeda dengan mereka yang hanya olahraga seminggu sekali atau tidak sama sekali. Meski begitu, orang yang lebih bugar juga bisa terinfeksi virus corona Covid-19. Tetapi, gejalanya tidak terlalu parah dan mereka akan sembuh lebih cepat.

\section{Bahaya terlalu banyak olahraga}

Olahraga terlalu sering bisa menjadi bumerang bagi kesehatan tubuh kita sendiri. Studi tahun 1990 menunjukkan 13 persen orang mengalami infeksi saluran pernapasan atas setelah maratin. Sedangkan, pelari biasa (tidak marathon) hanya 2 persen yang menderita penyakit tersebut.

Penelitian ini membuktikan bahwa olahraga dengan intensitas tinggi bisa memicu tubuh melepaskan zat kimia stres, seperti kortisol. Zar kimia ini bisa melemahkan sistem kekebalan tubuh, seperti stres psikologis.

\section{Hubungan olahraga dan corona Covid-19}

Sekarang ini belum ada penelitian yang mengaitkan dampak olahraga pada corona Covid-19. Tapi, Tamara Hew-Butler, Associate Professor Latihan dan Ilmu Olahraga bersama Profesor Marian Fahlman di Wayne State University di Detroit telah meninjau pengaruh olahraga dengan sistem 
imun. Penelitian ini mengatasi orang frekuensi olahraga dari 24 ribu orang dewasa di Tiongkok yang meninggal selama epidemi flu Hongkong 1998. "Studi ini menunjukkan bahwa orang yang tidak melakukan olahraga sama sekali atau terlalu sering (lebih dari 5 hari per minggu) berisiko besar meninggal dunia karena flu dibandingkan orang yang olahraga secara cukup," kata para ilmuwan.

Namun, Fahlman mengingatkan irang yang memiliki gejala corona Covid-19 tidak disarankan olahraga dulu. Sedangkan orang yang mungkin sudah terinfeksi tapi belum menunjukkan gejala, olahraga mungkin bisa membantunya."Karena orang yang belum menunjukkan gejala masih dalam masa inkubasi, yang artinya harus meningkatkan sistem kekebalan tubuh," kata Fahlman.

Dokter menyarankan Olahraga di Dalam Ruangan selama Wabah Corona

Melakukan olahraga di tengah anjuran tinggal di rumah selama wabah corona (Covid19) berlangsung jadi tantangan tersendiri. Padahal, aktivitas olahraga di luar ruangan sambil mendapat sinar matahari juga diperlukan demi menjaga daya tahan tubuh.

Dokter Spesialis Jantung, Sony Hilal, menyatakan bahwa berolahraga di luar ruangan masih terbilang aman selama membuat jarak dan menghindari kerumunan. Namun, dia menyarankan untuk sebaiknya dilakukan di dalam rumah saja, mengingat banyak latihan fisik yang tetap bisa diterapkan. Olahraga sebaiknya kalau bisa di rumah, bisa dengan squad, push up, sit up, kemudian mungkin jumping jack, lari di tempat, yoga dan semacamnya," menurut Sony mengacu pada studi dari New England Journal of Medicine yang mencatat bahwa ada kemungkinan virus corona Covid-19 bertahan di aerosol. Aerosol tersebut bisa bertahan 10-30 menit di udara dan ketika jatuh karena gravitasi dapat menempel pada benda. Di samping itu, berolahraga di dalam rumah dapat menghindari situasi yang tak diinginkan, termasuk paparan virus corona dari orang yang ditemui di luar rumah. "Kalau ada, bisa dimanfaatkan alatnya di rumah, treadmill atau sepeda statis kalau punya. Sementara ini, semua dokter sepakat untuk tidak menganjurkan keluar dari rumah apalagi berkumpul,

Olaharaga yang aman dilakukan selama Pandemik. Semenjak Organisasi Kesehatan Dunia (WHO) mengimbau kita untuk melakukan physical distancing, banyak yang berubah dari cara kita hidup sehari-hari. Tak hanya melakukan proses belajar mengajar, bekerja, dan beribadah di rumah, para atlet dan orang-orang yang gemar berolahraga luar ruangan juga sangat kecewa. Mereka terpaksa harus membatasi olahraga di pusat kebugaran, atau di arena olahraga lainnya.

Bukan berarti kamu jadi berhenti berolahraga selama pandemi COVID-19 ini. Lakukan olahraga dengan intensitas yang tepat. studi besar pernah membuktikan bahwa olahraga ringan hingga sedang yang dilakukan sekitar tiga kali seminggu mampu mengurangi risiko kematian selama wabah flu Hong Kong pada tahun 1998.Sementara orang yang tidak berolahraga sama sekali atau terlalu banyak berolahraga (lebih dari lima hari berolahraga per minggu), berada pada risiko kematian terbesar dibandingkan dengan orang yang berolahraga cukup. Jadi, pastikan kamu tetap berolahraga rutin dengan intensitas sedang supaya tetap sehat selama pandemi COVID-19 ini berlangsung.

Berikut ini jenis olahraga yang terbilang aman dilakukan untuk di rumah selama pandemi COVID-19, yaitu:

Kardio. Jenis olahraga kardio adalah olahraga yang efektif membakar lemak dan membuat tubuh berkeringat. Untungnya olahraga ini bisa dilakukan di rumah sehingga mengurangi risiko kamu terjangkit COVID-19. Jika kamu memiliki treadmill, sepeda statis atau alat kardio lainnya di rumah, maka kamu bisa memanfaatkannya. Namun, jangan khawatir, lompat tali atau skipping juga bisa menjadi alternatif.

Senam Aerobik. Jika tidak memiliki alat latihan kardio, kamu bisa melakukan senam aerobik yang memiliki manfaat yang serupa. Olahraga satu ini juga menjadi pilihan yang menarik untuk dilakukan selama di rumah. Kamu bisa melakukan senam zumba misalnya, dengan mengikuti video tutorial atau bahkan bersama teman-teman di rumah masing-masing 
lewat video conference. Instruktur olahraga aerobik tetap memberikan gerakan-gerakan yang membuat tubuh berkeringat sehingga tubuh menjadi lebih bugar. Senam aerobik juga mampu meredakan gejala depresi dan gangguan cemas yang dihadapi selama pandemi ini.

Yoga. Olahraga ini mungkin terkesan mudah dan sederhana. Namun, jika dilakukan dengan sungguh-sungguh, olahraga ini juga tergolong efektif membakar lemak dan membuat tubuh berkeringat. Bonusnya lagi, beberapa gerakan yoga dapat membuat kamu lebih tenang dan santai. Sehingga kecemasan yang sering muncul selama pandemi ini bisa berkurang. Beberapa manfaat yoga lainnya adalah menjaga metabolisme tubuh, meningkatkan pernapasan, memperkuat energi serta vitalitas. Kamu bisa melakukannya di rumah dengan mengikuti video tutorial yang banyak tersedia di internet.

Menari. Aktivitas menyenangkan ini juga bisa dihitung olahraga, lho! Kamu bisa nyalakan lagu favoritmu, atau sambal melihat video artis kesukaanmu. Menari juga tergolong sebagai olahraga karena meningkatkan ketahanan dan kekuatan tubuh. Kamu juga bisa berkeringat saat menari, karena menari membuat tubuh lebih aktif dan terus bergerak.

Push-up. Olahraga ini juga bisa dilakukan di rumah dan untungnya kamu juga tidak memerlukan alat bantu. Push-up adalah olahraga yang tepat jika kamu ingin memperkuat tubuh bagian atas, seperti dada. Jika rutin dilakukan setiap hari, maka dapat meningkatkan kekuatan otot dada dan tubuh menjadi lebih fit.

Lakukanlah olahraga rutin dan terapkan pola makan sehat dan tidur cukup agar sistem imun kamu cukup kuat untuk melawan virus dan penyakit lainnya. Olahraga dengan intensitas yang cukup sangat dianjurkan. Sebab, hal ini dapat menurunkan risiko terinfeksi virus corona.

"Jika seseorang jarang berolahraga maka risiko terinfeksinya tinggi, sedangkan jika olahraga cukup, tingkat risiko terinfeksinya rendah,"Adapun durasi ideal berolahraga, menurut Andi, yaitu cukup dengan waktu 30 menit hingga satu jam. Apabila olahraga di atas satu jam, lanjut dia, justru akan membuat daya tahan tubuh menjadi lemah dan rentan.
Terkait kondisi virus corona yang semakin mewabah, Andi juga sangat menganjurkan untuk berolahraga di dalam rumah.

"Kalau mau outdoor boleh boleh saja asalkan daerah olahraga tidak terkena wabah corona, kondisi badan sedang fit dan disarankan olahraga secara individual dengan perhatian jarak 1,5 hingga 2 meter," " Rutin berolahraga dengan intensitas cukup dapat meningkatkan daya tahan tubuh. Tak hanya itu, olahraga juga menjadi salah satu faktor penting melawan dan mencegah virus corona yang akan sembuh sendiri dengan daya tahan tubuh kita.

\section{PEMBAHASAN}

Aktifitas fisik dapat menjadi salah satu cara untuk mencegah penularan virus COVID19 ini. Pasalnya, menurut hasil penelitian, orang yang rutin berolahraga lebih jarang terserang penyakit dibandingkan dengan orang yang jarang berolahraga. Hal ini disebabkan karena ketika berolahraga, kinerja sel darah putih akan terangsang. Sel darah putih ini yang berfungsi sebagai antibodi untuk melawan berbagai jenis kuman yang masuk kedalam tubuh. Olahraga dipercaya dapat membantu mengeluarkan bakteri dari paru-paru yang memungkinkan tubuh terkena gejala flu dan penyakit lainnya. Ketika olahraga, suhu tubuh juga mengalami peningkatan. Hal ini dapat menghambat bakteri untuk berkembang dalam tubuh, dan dengan suhu tubuh yang meningkat juga dapat membantu tubuh melawan infeksi. Selain itu, dengan aktif berolahraga juga dapat mengurangi hormon stress di tubuh dan memperbanyak hormone endorfin yang berguna untuk sebagai obat penghilang sakit alami dan penyenang suasana hati (hormon bahagia).

Maraknya penyebaran virus COVID-19 ini berdampak terhadap banyaknya pusat kebugaran yang tidak beroperasi. Banyak sekali yang bertanya, bagaimana tetap berolahraga jika hanya dengan dirumah? Olahraga dapat dilakukan dengan homeworkout. Tidak memerlukan alat-alat yang terlalu berlebihan, dan dapat diakses dengan mudah secara online.

Selain itu, terdapat beberapa tips agar tetap semangat berolahraga saat pandemi dan 
tetap aman, yang dikutip dari saran Tamara Hew-Butler.

1. Lakukan aktivitas fisik sedang selama 20-45 menit, tiga kali seminggu.

2. Usahakan melakukan latihan kekuatan atau fitnes selama masa isolasi diri.

3. Hindari kontak fisik selama berolahraga, misalnya olahraga yang melibatkan tim, karena ini bisa membuat anda terpapar cairan mukosa atau kontak langsung dengan orang yang mungkin terinfeksi.

4. Cuci dan desinfeksi peralatan olahraga Anda setelah digunakan.

5. Berkomunikasi dengan rekan satu tim melalui media sosial daripada bertemu langsung.

6. Makan dan tidur cukup untuk meningkatkan sistem kekebalan tubuh.

7. Tetap optimistis pandemi covid-19 akan berlalu.

\section{Contoh-contoh Olahraga yang Dapat Dilakukan}

Beberapa jenis olahraga sederhana yang dapat anda lakukan ketika di rumah adalah:

\section{Kardio}

Tidak hanya untuk memperkuat jantung anda, kardio seperti bersepeda statis, melakukan jumping-jack, high knees, burpees, switch jumps, senam aerobik di rumah dipercaya dapat meningkatkan sistem imunitas anda.

\section{Angkat Beban}

Olahraga dengan menggunakan satu set alat resistance band (untuk kekuatan otot), dapat digunakkan untuk otot punggung, bisep, trisep, bahu, maupun kaki. Untuk memperkuat otot glut, dapat digunakan pita melingkat pada paha atau betis.

Selain itu, olahraga dengan menggunakan beban tubuh anda sendiri juga dapat dilakukan seperti sit up, push up, pull up, dan lain sebagainya.

\section{Yoga}

Olahraga yang tidak terlalu berat seperti yoga dipercaya dapat membantu menjaga sistem kekebalan tubuh secara optimal. Keadaan yang penuh tekanan seringkali dapat mempengaruhi imunitas anda secara negatif. Yoga yang dilakukan secara santai dapat menjadi pilihan bagi anda yang kurang menyukai olahraga berat.
Selain itu, yoga juga dapat meningkatkan fleksibilitas anda.

\section{Menari}

Menari merupakan kegiatan universal yang dapat dilakukan oleh segala usia. Menari dipercaya dapat melepaskan rasa stress dengan membiarkan tubuh anda aktif bergerak mengikuti irama lagu tertentu. Menari juga dapat menjadi hobi baru yang bisa anda lakukan disela-sela social distancing ini. Beberapa penelitian menyebutkan bahwa menari lebih baik dibandingkan olahraga lari dan membakar kalori yang lebih banyak. Selain itu, menari juga merupakan olahraga yang cenderung mudah dan dapat dilakukan kapan saja. Olahraga dapat membuat tubuh anda merasa lebih energetik dan sehat. Olahraga juga dapat meningkatkan rasa kepercayaan diri. Walaupun manfaatnya sangat baik, namun tidak disarankan untuk melakukan olahraga secara berlebihan.

\section{KESIMPULAN}

Sejak masuknya Covid-19 di Indonesia, masyarakt diminta untuk tetap di rumah dan melakukan segala sesuatu dari rumah. Selama di rumah saja mungkin banyak orang yang akhirnya sulit menjaga kesehatan karena tidak bisa berolahraga di luar rumah seperti biasanya atau terlalu banyak bermalas-malasan di rumah.

tetap bisa hidup sehat selama di rumah dengan mengikuti tips

di rumah selama pandemi Covid-19:

1. Menjaga kebersihan

Menurut Suara.com Menjaga kebersihan adalah salah satu hal yang wajib dilakukan di tengah pandemi seperti sekarang ini. Di saat seperti ini, menerapkan hidup bersih bisa menghindarkan kita dari infeksi virus dan bakteri penyebab penyakit, termasuk virus corona.

Cara paling sederhana untuk menjaga kebersihan di tengah pandemi adalah mencuci tangan dengan teratur dan menyemprot barang-barang yang sering disentuh menggunakan desinfektan.

2. Mengkonsumsi makanan sehat

Mengonsumsi lebih banyak buahbuahan dan sayur-sayuran merupakan satu di antara pola hidup sehat, sangat penting 
dilakukan ketika masa pandemi virus corona saat ini.

Buah dan sayur juga merupakan sumber serat, vitamin dan mineral, serta senyawa penting lain yang dibutuhkan tubuh.

lemari $\begin{array}{ccc}\text { Simpan buah-buahan dan sayuran di } \\ \text { es untuk memungkinkan }\end{array}$ mempertahankan nutrisi yang terkandung, selain dimakan saat segar.

Dengan sering mengkonsumsi sayursayuran dan buah-buahan tubuh kita juga akan lebih sehat dan juga dapat menambah daya tahan tubuh terhadap bakteri atau virus seperti covid-19 ini.

\section{Berolahraga}

Agar tubuh dan pikiran tetap sehat selama dirumah, selain berjemur anda harus tetap meluangkan waktu untuk berolahraga. Tidak perlu olahraga berat, olahraga ringan seperti lari-lari kecil di sekitar rumah sudah cukup untuk membuat badan tetap bergerak.

Selain itu, lakukan aktivitas fisik di rumah seperti membersihkan rumah juga efektif sebagai pengganti olahraga di luar rumah.

Dengan olahraga rutin setiap hari dapat menjaga tubuh agar tetap sehat, terutama dapat meningkatkan daya tahan tubuh agar terlindungi dari virus.

4. Periksa diri sendiri

Salah satu cara paling membantu mencegah makan berlebih adalah untuk memahami mengapa hal itu terjadi. Ada banyak alasan mengapa Anda mungkin harus makan berlebihan, termasuk stres atau bosan.

Jika mendapati diri Ada makan terlalu sering atau makan terlalu banyak dalam satu waktu, luangkan waktu sebentar dan periksa diri sendiri. Pertama, penting untuk menentukan apakah Anda makan karena lapar dan butuh makanan, atau apakah ada alasan lain.

Sebelum makan, berikan perhatian khusus pada perasaan Anda, seperti stres, bosan, kesepian, atau cemas. Cukup berhenti dan mengevaluasi situasi dapat membantu Anda memahami apa yang memaksa Anda untuk makan berlebihan dan dapat membantu mencegah makan berlebihan di masa depan.

Jika merasa sulit melawan rasa ingin makan, Anda mungkin harus mencari bantuan profesional. Terutama jika itu adalah kejadian umum atau Anda makan sampai merasa tidak nyaman dan mengalami perasaan malu atau bersalah sesudahnya, mungkin itu tanda-tanda gangguan makan.

5. Penuhi kebutuhan cairan tubuh

Konsumsi minimal 2 liter air atau setara 8 gelas setiap harinya. Air memiiki banyak manfaat, seperti menyalurkan kadar oksigen ke seluruh sel tubuh, sehingga sistem peredaran darah tetap lancar. Selain itu, air data membersihkan racun berbahaya dari tubuh dan menjaga fungsi ginjal.

Selalu letakkan botol berisi air di dekatmu atau meja kerja saat di rumah. Atau kamu bisa memasang alarm di smartphone yang mengingatkanmu untuk memenuhi kebutuhan cairan.

\section{DAFTAR PUSTAKA}

Alam, SPP, 2020, tips hidup sehat dirumah selama pandemic covid -19 , situs suara.com

Azizah Nora, 2020, antisipasi corona dengan rutin berolahraga, situs repoblika.co.id

CNN Indonesia, CNN Indonesia, Dokter Sarankan Olahraga di Dalam Ruangan selama Wabah Corona, situs cnn Indonesia

Fernandes Riandi, 2020, manfaat olahraga untuk mencegah virus covid-19. Situs arsip sehat.com

M. Reza Sulaiman ,Shevinna Putti Anggraeni. Demi Kekebalan Tubuh, Ini Anjuran Frekuensi Olahraga untuk Tangkal Corona, situs Suara.com

Makarim, F, R. 2020. Ini Olahraga yang Aman Dilakukan Selama Pandemi Corona. Situs Halodoc.

Putsandra, 2020 Baca selengkapnya di artikel "Jaga Daya Tahan Tubuh dengan Olahraga Saat Pandemi Corona COVID-19", https://tirto.id/eKqi2020. Ini Olahraga yang Aman Dilakukan 
Terakreditasi Peringkat 5 (No. SK: 85/M/KPT/2020)

Selama Pandemi Corona. Situs Halodoc.

Zahra, 2020, tip berolahraga saat pandemic covid-19 menyambut new normal, situs zonautara.com 